\title{
ERASTUS THE AEDILE
}

\author{
David W.J. Gill
}

\section{The inscribed pavement}

During excavations on the site of the Roman colony at Corinth three fragments of two inscribed paving stones were found. ${ }^{1}$ They form the centre and right slabs of three adjoining inscribed slabs which were made of gray Acrocorinthian limestone. Each would have measured 0.66 (height) $\times 2.27$ (width) $x 0.15 \mathrm{~m}$ (thick), giving a total pavement width of $6.81 \mathrm{~m}$; a shallow gutter runs along the top edge. The Latin inscription was originally of bronze, and apart from two punctuation marks, all that remains are the cuttings for the letters, $0.18 \mathrm{~m}$ high, which appear in two lines. The inscription reads:

[praenomen nomen] Erastus for his aedileship

laid (the pavement) at his own expense

[praenomen nomen] Erastus pro aedilit[at]e s(ua) p(ecunia) stravit ${ }^{2}$

The location of the pavement is provided by the one complete slab (except for its lower right corner) which was

\footnotetext{
${ }^{1}$ E.g. T.L. Shear, 'Excavations in the Theatre District and Tombs of Corinth in 1929', AJA 33 (1929) 525-6, fig. 9; F.J. De Waele, 'Erastus, oikonoom van Korinthe en vriend van St. Paulus', Mededeelingen van het Nederlandsch historisch Institut te Rome 9 (1929) 40-8; A.M. Woodward, 'Archaeology in Greece, 1928-1929', JHS 49 (1929) 221; F.J. De Waele, 'Die Korinthischen Ausgrabungen 1928-1929', Gnomon 6 (1930) 54; id., Gnomon 10 (1934) 226; A.G. Roos, 'De titulo quodam latino Corinthi nuper reperto', Mnemosyne 58 (1930) 160-5; H.J. Cadbury, 'Erastus of Corinth', JBL 50, 2 (1931) 42-58; R. Stillwell, The Theatre (Corinth ii, American School of Classical Studies at Athens, Princeton [NJ], 1952) 4, pl. ii; P.N. Harrison, 'Erastus and his pavement', Paulines and Pastorals (London 1964) 100-5; J.H. Kent, The Inscriptions 19261950 (Corinth viii,3, American School of Classical Studies at Athens, Princeton [NJ], 1966) 99-100, pl. 21, no. 232 (with earlier bibliography). It should be remembered that studies prior to 1947 could not take account of the full inscription. See plan on p. 293; reproduced by courtesy of the American School of Archaeology at Athens.

${ }^{2}[]$ indicate lost text; $O$ indicate an expansion of Latin abbreviations.
} 
found in 1929 in situ in the square east of the stage building of the theatre. Together they lay at the entrance to the square from the street which runs along the east side of the theatre. The left portion of the second slab had been found in the previous year in the east parados of the theatre, and the rest in the basement of a late vaulted building southwest of the theatre in 1947. The square (c. $19 \times 19 \mathrm{~m}$.) was itself paved in limestone blocks, and may be considered as an integral part of the gift.

\section{Erastus the aedile}

What were the circumstances surrounding the gift of this pavement? Corinth was a Roman colony, established on the site of the ruined hellenistic city, and founded by Julius Caesar in $44 \mathrm{BC}$. As a result its government was Roman in character. The city was divided into tribes, and there was a council formed by decuriones. The chief magistrastes, elected each year, were the duoviri; every fifth year they were termed duoviri quinquennales when they took a census and revised the membership of the council. Below the duoviri was a pair of aediles, again elected annually. They were responsible for the maintenance of public streets and buildings, which included the market places, they managed the revenues derived from such places, and they served as judges. In most colonies the aediles were also responsible for the public games but not at Corinth. The colony took charge of the administration of the internationally important games at Isthmia, which it did through the appointment of an agonothetes or president; judging from the careers of Corinthians this was considered to be one of the most prestigious posts. ${ }^{3}$

The Erastus of our inscription had held this important post. Although he had a praenomen, a nomen (both lost) and a cognomen (Erastus), there does not appear to have been space for his father's name or his tribe, which suggests that Erastus

${ }^{3}$ E.g. The career of [L. Castri]cius Regulus (or possibly [Cn. Publi]cius Regulus) is as follows: aedile, prefect iure dicundo [substitute for the duovir], duovir, quinquennial duovir, agonothete (Kent, The Inscriptions 1926-1950 no. 153). 
was a freedman. ${ }^{4}$ Freedmen could, however, be extremely wealthy, hold high public office and become important benefactors. For example $\mathrm{Cn}$. Babbius Philinus, another freedman, also held the post of aedile, and in his capacity as duovir built a circular monument with eight Corinthian columns on which was recorded his career..$^{5}$ Another freedman is C. Heius Pamphilus, who although not recorded as holding the post of aedile, had a fairly remarkable career: twice duovir, twice prefect in place of the duovir, and agonothete. ${ }^{6}$ Pamphilus seems to have had a brother, Aristo, again a freedman of the same C. Heius. He held the posts of aedile, duovir and duovir quinquennalis. ${ }^{7} \mathrm{~A}$ third freedman of the same man is C. Heius Pollio who was also a duovir under Augustus. ${ }^{8}$

The setting up of a monument by an aedile, at his own expense, seems to have been quite common. In the first century $\mathrm{AD}$ an aedile named Hicesius (both his praenomen and nomen are missing), had a building constructed 'with the official permission of the city council'. The building has not been identified. ${ }^{9}$ Both this building and Erastus' pavement are likely to have been a fulfilment of pledges made to celebrate

${ }^{4}$ The second line of the inscription is centred in the middle block and is therefore complete. This means that seven letters would have appeared on the left hand block before Erastus. If the praenomen was abbreviated (e.g. M. or $\mathrm{Cn}$.) this would leave six or five spaces for the nomen.

${ }^{5}$ A.B. West, Latin inscriptions 1896-1926 (Corinth viii,2, Harvard University Press, Cambridge [Mass.], 1931) no. 132; Kent, The Inscriptions 1926-1950 no. 155; R.L. Scranton, Monuments in the Lower Agora and North of the Archaic Temple (Corinth i,3, American School of Classical Studies at Athens, Princeton [NJ], 1951) 17-32. More recently he has been linked with the fountain of Neptune (Poseidon) recorded by Pausanias (ii.2.7): see C.K. Williams, II, in H.W. Catling, 'Archaeology in Greece, 1986-87', Archaeological Reports 33 (1986-87) 16, fig. 21; West, Latin inscriptions 1896-1926 nos. 2-3.

${ }^{6}$ His career is known from an inscription (Kent, The Inscriptions 1926-1950 no. 150) and coins which were issued during his time as duovir between 34 and 31 , $27 / 26$ or $26 / 25$, and $17 / 16$ BC: $M$. Amandry, Le monnayage des duovirs corinthiens ( $B C H$, suppl. 15, École française d'Athènes, Paris, 1988) 38-39, 4749, 54-55, Issues VI, VIII, and IX.

7Kent, The Inscriptions 1926-1950 no. 151.

${ }^{8}$ Amandry, Le monnayage des duovirs $47-49$, Issue VIII (with C. Heius Pamphilus).

${ }^{9}$ Kent, The Inscriptions 1926-1950 no. 231. 
elections. ${ }^{10}$ Erastus' pavement may find a parallel at Venusia in Apulia where an aedile, C. Flaminius Gallus, son of Gaius, also made a similar gift. ${ }^{11}$ In addition to paying for such public monuments-which would have been appropriate for marking the aedileship where responsibilities included public buildings and streets-the aedile was expected to pay a charge for holding the office. Although the costs are not known for Corinth, evidence from North Africa and Italy suggests sums in the region of HS 4,000 to HS 20,000, depending on the size of city. ${ }^{12}$ Thus these freedmen were likely to have had substantial means.

\section{Erastus olkovónos Tfis moגeదిs}

At the end of Paul's epistle to the Romans, almost certainly written from Corinth, ${ }^{13}$ there appears a list of greetings from individuals: one is from Erastus oikonomos of the city. What is the equivalent to the post of oikonomos in the Roman colony of Corinth? ${ }^{14}$ An oikonomos is recorded on a Late Roman Christian grave slab from a cavern at Lerna (Corinth). It is inscribed on one side: "The grave of Loukas the guardsman (exkoubitoros), [which] he bought from Andreas the oikonomos in the month of February [--- ] ${ }^{15}$ Here are recorded two imperial employees, perhaps slaves. However the use of the term oikonomos in this

${ }^{10}$ On which see: P. Garnsey, 'Taxatio and pollicitatio in Roman Africa', JRS 61 (1971) 116-29. For an example from Corinth, see the benefaction of P. Licinius Priscus Juventianus at Isthmia which includes part of his campaign promise: IG iv, 203.

${ }^{11}$ CIL ix, 442.

${ }^{12} \mathrm{R}$. Duncan-Jones, 'Costs, Outlays and summae honorariae from Roman Africa', PBSR 30 (1962) 103, nos. 349-353a; id., The Economy of the Roman Empire. Quantitative Studies (Cambridge, CUP 1974) 82-88, 108-10, 154 . Cf. B.W. Winter, 'Secular and Christian Responses to Corinthian famines', TynB 40 (1989) 105-6 n. 89.

${ }^{13}$ E.g. C.E.B. Cranfield, A Critical and Exegetical Commentary on the Epistle to the Romans (T. \& T. Clark, Edinburgh 1975) 1, 12. The main evidence is that the letter commends Phoebe from Cenchreae, the eastern port of Corinth (Rom. xvi.1) and that Paul's host was one Gaius (Rom. 16:23; cf. 1 Cor. 1:14).

${ }^{14}$ See H.J. Mason, 'Greek Terms for Roman Institutions.-A Lexicon and Analysis' (ASP 13 Hakkert, Toronto 1974).

${ }^{15}$ Kent, The Inscriptions 1926-1950 no. 558. 
late context need not reflect the use of the term in the first century AD. ${ }^{16}$

However, the post of oikonomos. had not always been seen as an inferior position. At Philadelphia a sophist could be honoured with the post of oikonomos of the city, and elsewhere this term 'refers to a high position' ${ }^{17}$ It is true that some oikonomoi could be freedmen, but the colony of Corinth was settled by freedmen ${ }^{18}$ and we have seen that they could be extremely wealth and hold high office.

What was the equivalent Latin term for the post of oikonomos in a Roman colony such as Corinth? H.J. Mason has argued, using the Erastus inscription and ones from Philadelphia and Izmir, that the Greek term oikonomos was the equivalent of an aedile. ${ }^{19} \mathrm{G}$. Theissen, however, tries to argue that the term oikonomos was the equivalent of the term quaestor. ${ }^{20}$ He points out that $P$. Licinius Priscus Juventianus promised that if he were to be elected to office he would erect new public buildings on the condition that he was sold 'the ruins of the so-called Stoa Regulana'.21 The text of the inscription also gives a list of the buildings which Priscus had constructed and repaired at Isthmia and adds, in return for his aedileship' (ümép àropavoplas). Thus by the second century

${ }^{16}$ There is no need to see this inscription as evidence for a Christian holding the position of aedile: Winter, 'Responses to Corinthian famines' $105 \mathrm{n} .89$. G. Theissen,The Social Setting of Pauline Christianity. Essays on Corinth (ET; Fortress Press, Philadelphia 1982) does not discuss this inscription, but much of his evidence comes 'from the period of the later empire' (78).

${ }^{17}$ Theissen, Social Setting 77. See also Cadbury, 'Erastus of Corinth', 48-51 for a discussion of the term, drawing on P. Landvogt, Epigraphische Untersuchungen uber den oıkovopos: ein Beitrag zum hellenistischen Beamtenwesen (Diss. Strassburg, 1908).

18 Strabo viii.6.23.

${ }^{19}$ Mason 'Greek Terms' 71. The other equivalents are 1) actor, 2) dispensator, and 3) vilicus.

${ }^{20}$ Theissen Social Setting 79-82.

21 IG iv, 203; O. Broneer, 'An official rescript from Corinth', Hesperia 8 (1939) 181-90; L. Robert, Hellenica 1 (1940) 43-53; Kent, The Inscriptions 1926-1950 120-1. The career of Licinius Priscus has been adjusted so that this work was carried out not around AD 170 but before around AD 110: B. Puech, 'Grandsprêtres et helladarques d'achaïe', REA 85 (1983) 15-43, esp. 35-41. 
$\mathrm{AD}$ the aedileship at Corinth could be termed agoranomos. ${ }^{22}$ Theissen argues that in the first century AD Paul should have used the term agoranomos if he had meant aedile, and thus looks for a junior post such as quaestor. However this post is the equivalent of the Greek tamias. ${ }^{23}$

J.H. Kent saw no problem in both terms, agoranomos and oikonomos, being the equivalents of aedile. ${ }^{24}$ In particular he points out that although in most colonies the aediles would have been responsible for the public games, at Corinth, because of the nature of the festival at Isthmia, this aspect of their duties were dealt with by other, more senior, officials, the agonothetai. Therefore the term oikonomos may have been particularly apt for the Corinthian situation, and as Kent reminds us it 'describes with reasonable accuracy the function of a Corinthian aedile' ${ }^{25}$

\section{Erastus the aedile and Erastus the oikonomos}

Are we to identify the Erastus inscription with the Erastus of Romans? It needs to be pointed out that the evidence will not allow a certain identification or a certain rejection. The earliest reports proclaimed the find as a link between the New Testament documents and the archaeological record, ${ }^{26}$ but are we right to accept them? Some of the earliest commentators on the inscription were opposed to the association. ${ }^{27}$ H.J. Cadbury felt that the identification of the two Erasti as the same man was 'improbable if not impossible', ${ }^{28}$ as he felt that an oikonomos was a slave and that 'no Christian could consent to

${ }^{22}$ See also Kent, The Inscriptions $1926-1950$ no. 308 , which uses the term agoranomos. Cf. Mason 'Greek Terms' 19.

23 Mason 'Greek Terms' 91; J. Wiseman, 'Corinth and Rome I', ANRW 7,1 (1979) 499. Theissen does not cite Mason's analysis.

${ }^{24}$ Kent, The Inscriptions 1926-1950 27.

25 Kent, The Inscriptions 1926-1950 100. Dr A. J. S. Spawforth reminds me that we might expect Paul, as a native of Tarsus, to have been familiar with the Greek civic vocabulary of his time.

${ }^{26}$ Shear 'Excavations in the Theatre District' 526 . Erastus is here identified as a procurator due to the incomplete nature of the text. Shear describes the link as 'most probable'.

27E.g. Roos, 'De titulo'.

${ }^{28}$ Cadbury, 'Erastus of Corinth' 58. 
the paganism involved in holding such an office as aedile'.29 However since then opinion seems to have favoured the possibility of a connection. O. Broneer has seen Erastus the aedile as 'probably the same Erastus who became a co-worker of St. Paul' ${ }^{30}$ Likewise J.H. Kent, who published the Erastus inscription in the corpus of inscriptions excavated at Corinth, commented that 'the original suggestion that Erastus [i.e. the aedile] is to be identified with the Corinthian Erastus of the New Testament (Romans, xvi, 23) still seems sound'. ${ }^{31}$ Kent maintained this position because the inscription probably dated to the middle of the first century $A D$, the cognomen Erastus was not common at Corinth, and the term oikonomos could correspond with the office of aedile.

G. Theissen's position as identifying the oikonomos with the post of quaestor, which was held by a freedman, should thus be taken as removing Cadbury's objections as well as a move towards allowing the two to be the same man. V.P. Furnish seems to follow Theissen ${ }^{32}$ by suggesting that Erastus was originally a quaestor (= oikonomos), and later an aedile, and accepts 'that this Erastus [i.e. the aedile] is the same one whom Paul and the author of 2 Timothy mention'.$^{33} \mathrm{R}$. Lane Fox, also following Theissen, however is dismissive of any identification. Although he allows an oikonomos to be an 'eminent post', he maintains that it was normally held by a public slave. He concludes it is quite uncertain whether this man could be the Erastus whom a recent inscription in Corinth's theatre revealed as a freeborn magistrate, the aedile of the colony' ${ }^{34} \mathrm{C}$.J. Hemer felt that there was 'no sufficient reason to affirm either of these identifications' but points to evidence to

${ }^{29}$ Cadbury, 'Erastus of Corinth' 55 . The same objections are put forward by Roos, 'De titulo' 164-5), citing in particular Pliny Epist x.96.

${ }^{30} \mathrm{O}$. Broneer, 'Corinth, center of St Paul's missionary work in Greece', BA 14,4 (1951) 94. Cf. W.A. McDonald, 'Archaeology and St. Paul's journeys in Greek lands, part iii - Corinth', BA 5,3 (1942) 46.

31 Kent, The Inscriptions 1926-1950 99. However he does seem to have misunderstood the position held by Cadbury.

${ }^{32}$ He however provides no reference to Theissen.

${ }^{33}$ V.P. Furnish, 'Corinth in Paul's time. What can archaeology tell us?', $B A R$ 15,3 (1988) 20.

${ }^{34}$ R. Lane Fox, Pagans and Christians (Harmondsworth, Penguin 1988) 293. 
show that prominent people at Ephesus had the cognomen of Erastus. ${ }^{35}$

\section{Conclusion}

How are we to interpret this epigraphic evidence? Some (e.g. Roos, Cadbury, Lane Fox) have taken the view that an oikonomos was a slave, which would not allow a link with Erastus the aedile. However, this does not explain why Paul draws attention to this man's standing in society, something he rarely does. The context of the epistle to the Romans may be of help here. In it Paul commanded: 'Do the good (deed) and you shall have praise from the (civil) authority'.36 Does Paul emphasise the status of Erastus because here is a Christian official who has indeed become a benefactor of his city, possibly in his capacity as aedile ${ }^{37}$ In contrast, one of Cadbury's objections to Erastus the aedile being the same as Erastus the oikonomos was that no Christian would hold the office of aedile. The evidence does not allow us to be certain about the link between the two Erasti, but at the very least it is clear that Paul is here reminding Christians to take an active role in the running of the city just like Erastus the oikonomos. ${ }^{38}$

${ }^{35}$ C.J. Hemer (C.H. Gempf ed.), The Book of Acts in the Setting of Hellenistic History J.C.B. Mohr [Paul Siebeck], Tübingen 1989) 235.

${ }^{36}$ Romans 13:3.

37 The significance of this inscription has been seen by Winter, "The public honouring of Christian benefactors', JSNT 34 (1988) 95, 102 n. 45.

${ }^{38}$ I am grateful to A.J.S. Spawforth and B.W. Winter for their comments and advice. 


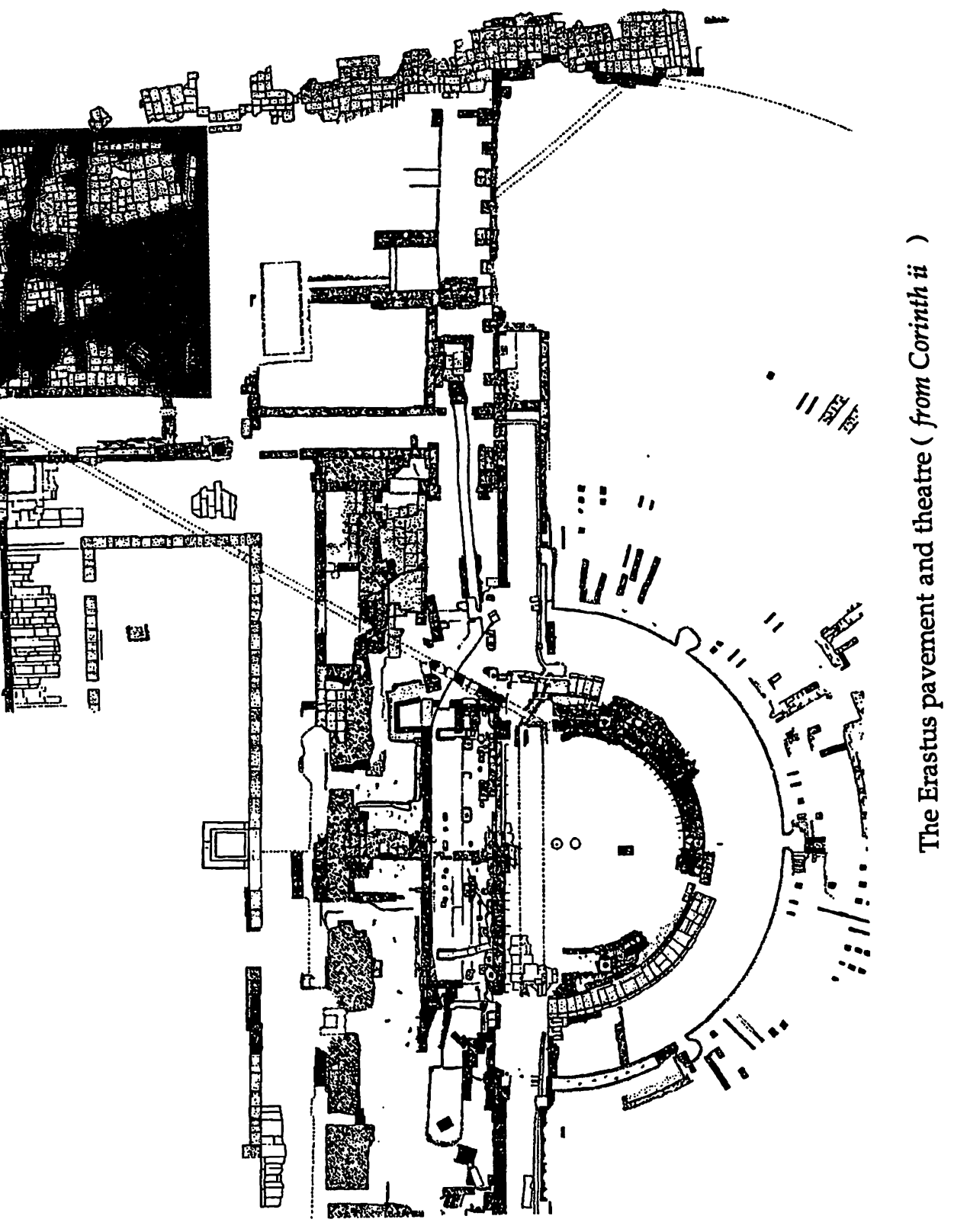

https://tyndalebulletin.org/

https://doi.org/10.53751/001c.30545 